\title{
Participatory environmental governance of infrastructure projects affecting reindeer husbandry in the Arctic
}

Mia Landauer ${ }^{1,2, *}$, Nadejda Komendantova ${ }^{2,3}$

${ }^{1}$ Arctic Centre, University of Lapland

P.O. Box 122 (Pohjoisranta 4), FIN-96101 Rovaniemi, Finland (present address)

Mobile+358 40484 4154, email mia.landauer@ulapland.fi

${ }^{2}$ Risk and Resilience Program

International Institute for Applied Systems Analysis (IIASA)

Schlossplatz 1, A-2361 Laxenburg, Austria

${ }^{3}$ ETH-Swiss Federal Institute of Technology

Institute for Environmental Decisions, Climate Policy Group

Universitätstrasse 22, CHN J 76.1 8092 Zürich, Switzerland

\section{Abstract}

Several infrastructure projects are under development or already operational across the Arctic region. Often the deployment of such projects creates benefits at the national, regional, or global scales. However, local communities can experience negative impacts due to the requirements for extensive land areas, which cause pressure on traditional land use. Public participation in environmental planning such as Environmental Impact Assessment (EIA) enables local communities to provide feedback on the environmental, social, and economic challenges of infrastructure projects. Ideally, participation can improve the means of social learning for all involved parties and help to co-develop sustainable solutions. The subject of our research is reindeer herders' participation in EIA procedures of mines and wind farms in Finland because these types of projects affect reindeer husbandry. We study empirically how stakeholders involved in the EIAs perceive the participation of reindeer herders in the planning and implementation of infrastructure projects, and how these differ from the perceptions of the reindeer herders who are affected by the infrastructure projects. Our qualitative data is based on in-depth semi-structured interviews $(\mathrm{N}=31)$ with members of the industry sector, consultants, governmental authorities, and representatives of local communities; in this study, the reindeer herders. The results show that herders' level of participation in the EIAs and the benefits and challenges of participation are perceived differently. Furthermore, the regulatory framework does not adequately ensure that the developer carries social and environmental responsibilities throughout the infrastructure project's lifecycle, and that regular communication with herders will also be maintained after the EIAs. Herders' expertise should be used throughout the project life cycle. For example, more attention should be paid to both negotiating possible options for compensation and monitoring mechanisms when the infrastructure projects are pre-screened for the EIAs, as well as to co-designing the different project alternatives with herders for the EIAs. *Corresponding author 
Keywords: traditional livelihoods; Environmental Impact Assessment; land-use; mining; wind farms; Finland

\section{Introduction}

The Arctic region is facing rapid changes caused by changing land use due to forestry, as well as infrastructure development such as mining, wind and hydropower, peat production, oil and gas extraction, and many others. The deployment of large scale infrastructure projects and extraction of natural resources can be beneficial to local communities, but they also create challenges such as land use conflicts and protests: this is particularly the case if they violate land rights and erode culture and traditional livelihoods of local and indigenous communities (Dale et al., 2018; Ross, 2018). As the local residents and indigenous communities have already been struggling with land use changes and abuses of land rights in the past (van Schie and Haider, 2015; Stammler and Ivanova, 2016), their capacity to adapt to these multiple changes is once again under the spotlight due to climate change (Forbes, 2007; Ford et al., 2008; Whyte, 2016). The involvement of local people and their knowledge during the planning, implementation, and monitoring phases of natural resource management can reduce the social and environmental impacts (Kearney et al., 2007). Therefore, participatory governance can help to deal with land use conflicts while aiming to develop compromise solutions based on the different opinions and views. However, heterogeneous perceptions of project developers, authorities, or the public regarding "effective participation" exist and identification of this "efficacy" is difficult. To some, participation seems efficient if local people are consulted, and to others participation is effective if it succeeds to reduce resistance (legitimation). Usually those affected by the projects, consider participation efficient only if their voices are truly influencing decision-making and planning (see O'Faircheallaigh, 2010).

\section{Conceptual background}

\subsection{Environmental Impact Assessment (EIA) for industrial infrastructure projects}

In many Arctic countries, such as Finland, Russia, and others, an Environmental Impact Assessment (EIA) is required for large-scale infrastructure projects such as mines that are likely to have considerable negative impacts on the environment (Koivurova et al., 2016). Basically, EIA allows public participation because public participation is at its core and lay people can comment on its outcomes. The "public" can be local residents, representatives of traditional livelihoods, or non-governmental organizations, such as environmental protection agencies.

The purpose of EIA in Finland is to reduce or prevent the negative environmental impacts of projects that could have a major impact on the environment while still allowing public participation in planning (Act on Environmental Impact Assessment Procedure 468/1994, 
substituted by 252/2017; Decree on Environmental Impact Assessment Procedure 713/2006, substituted by 277/2017). The Ministry of the Environment in Finland develops EIA policy and legislation in Finland. Land use in the reindeer husbandry area in Finland is mainly regulated by National Land Use Guidelines (Valtakunnalliset alueidenkäyttötavoitteet, VAT), Land Use and Building Act (Maankäyttö- ja rakennuslaki 132/1999), Reindeer Husbandry Act (Poronhoitolaki 848/1990) as well as by forest legislation (e.g., Act on Metsähallitus, Laki Metsähallituksesta 234/2016).

The developer submits the EIA assessment programme to the ELY Centre (Centre of Economic Development, Transportation and the Environment) for evaluation. The ELY is responsible for pre-screening and makes the decision whether an EIA is required. It also coordinates the EIA procedure and makes sure that public hearings required by law are organised. What is regarded as a "considerable impact" depends on the nature of the project and is case-specific. The Decree on EIA consists of details on the types of projects that require an EIA. The EIA is not a decisionmaking procedure, but an evaluating and planning procedure, which can inform policy (Koivurova et al., 2016). One of the main aims of the EIA in Finland is to encourage the participation of different parties in the planning phase before project implementation takes place. For example, the EIA assessment report has to be accepted before an environmental permit to implement the project can be given by the Regional State Administrative Agency (AVI) responsible for environmental and water permits and monitoring implementation. Usually the developer does not have the capacity to prepare the EIA, so a consultant is hired (see more details on the EIA procedure in Finland in Ministry of the Environment, 2013; Koivurova et al., 2016, 35-53). However, past experience of EIAs and the deployment of infrastructure projects in the Arctic has shown that the participation of local communities can be challenging (Koivurova et al., 2016; Stammler and Ivanova, 2016). This is, for example, due to the lack of holistic understanding of social, economic, and environmental consequences of the projects, especially in the long-term. Sometimes EIAs can be biased due to different opinions and views of stakeholders, sometimes even due to manipulation for example when developers want to hide some information (Enríquez-de-Salamanca, 2018).

\subsection{Land use changes and reindeer husbandry in the Arctic}

Social and environmental impacts are especially significant for traditional and indigenous livelihoods. Among existing livelihoods in the Arctic, reindeer husbandry is one of the most important indigenous and traditional livelihoods in the circumpolar Arctic and Barents region (Oskal et al., 2009; Rees et al., 2007). However, these livelihoods are being affected by existing industries in the region and also facing the risk of planned industrial infrastructure development and other land use changes (Herrmann et al., 2014; Kumpula et al., 2011; Vistnes et al., 2009). 
In Finland, there are differences in reindeer herding practices due to cultural and biogeographical differences. The sizes of individual herding cooperatives, and ownership across the cooperatives, the maximum size of the reindeer populations per individual herding 'cooperatives' (paliskunnat) are regulated. Reindeer husbandry is steered on the national level by the Ministry of Agriculture and Forestry and it belongs to agriculture sector under the European Union agricultural policy (Saarni and Nieminen, 2011).

Climate change together with rapid industrial development create new, "emerging" risks that cause much uncertainty for the future of reindeer husbandry in Finland. Climate change affects reindeer husbandry directly, for example, while reducing availability of forage in winter due to more frequent ground ice conditions (Turunen et al., 2016). Capacity to adapt to climate change and land use change varies across the reindeer husbandry area. For example, the access to suitable pastures has become limited especially due to intensive forestry practices throughout the history (Helle and Jaakkola, 2008) but also due to other land use factors (Kumpula et al., 2014). Land use changes affect the availability and quality of forage and pastures, the size of the pastures and the reindeer population. The land use changes also cause ecosystem degradation and increase supplementary feeding demand in winter (Anttonen et al., 2011; Heikkinen et al. 2012). It is inevitable that supplementary feeding changes the nature of reindeer husbandry and requires more financial resources, more time, and more work of herders, which cause economic impacts. But it can help overcome critical winters if digging conditions are difficult or (arboreal) lichens are lacking, and reindeer would otherwise starve. Changes in reindeer herding practices and agreements on compensation are needed if damages to property, as well as impacts and conflicts due to multiple land uses, will increase.

Currently several mining and wind farm projects are under development or already operational in the reindeer husbandry area in Finland which covers 36 percent of the total area of Finland (Fig. 1). The environmental impacts of mining can originate, for example, from wastewater spills and risks of such spill-overs can increase due to climate change because of increasing precipitation and extreme weather events (Northey et al., 2017). In the case of wind farms, pollution is not an issue, but power transmission lines that cut across the pastures, as well as potential noise impacts, can affect reindeer. More systematic and longer-term monitoring of reindeer behaviour is still needed while the impacts of wind farms on reindeer are still debated among scholars (cf. Colman et al., 2012; Flydal et al., 2004; Flydal, et al., 2009). Reindeer might avoid the area, have difficulties moving within the area, pastures will be fragmented, and calving disturbances may occur (Skarin et al., 2015). Furthermore, the increased traffic, particularly during the construction period, could cause injuries and the death of reindeer. 
Additionally, reindeer could also be disturbed by the dust and noise of the construction work, especially during the calving time.

\subsection{Participatory governance}

In general, with the phrase "public participation" we refer to any involvement of the public in all or some of the different phases of infrastructure project life cycle: initiating, planning, decision-making or follow-up (e.g. monitoring). "Participatory governance" means integration of views, knowledge, and values of local communities and civil society organisations into decision-making and planning of the projects. Following the definition of O'Faircheallaigh $(2010,20)$ we consider public participation in the EIAs as "any form of interaction between government and corporate actors and the public that occurs as part of EIA processes." However, we are also aware that the efficacy of participation can be perceived differently whether the project is iterative, whether participation can affect decision-making at all, or whether its outcomes mostly benefit the developer who might only consult the public (O'Faircheallaigh, 2010). That is why in our empirical study we use the Arnstein's Ladder of Citizen Participation (Arnstein, 1969) as a framework to identify different levels of participation ${ }^{1}$ and to understand what "efficient" participation means to different stakeholders in practice and how "effective" the EIA in Finland can be (cf. Bautista et al., 2017; Loomis and Dziedzic, 2018).

Participatory governance differs from hierarchical, "top-down" modes of governance. The latter are, for example, based on the knowledge transfer from science to policy-makers and then implemented through different levels of governance. Based on this knowledge transfer, planning decisions can be made, and projects can be implemented at the local level. Participatory governance involves grass-root movements and the concerns of lay-people. This is how it differs from the governance model based on the ruling of "educated experts" (Renn, 2008). In the theories on infrastructure planning governance, participatory governance is often connected with mechanisms, which facilitate the impact of participatory processes on strategic policy priorities on infrastructure (Groves et al., 2013). Thus, together with decentralisation, participatory governance is a key element in attempts to improve governance systems as it has the potential to increase the circulation of information, transparency, and accountability (Coelho and Favareto, 2011).

\footnotetext{
${ }^{1}$ Ladder I) 'Citizen power' is the highest and the most efficient level of participation where partnership, delegated power and citizen control can be identified, and where voices of the public are considered in decision-making and planning.

Ladder II) 'Tokenism' is a level at which informing, consultation, placation, and one-way flow of information can be identified: the public is being consulted but this does not have real influence on decision-making or planning.

Ladder III) 'Non-participation': there are no participation possibilities or participation has no influence in decision-making or planning, but instead, power holders rather "educate" or "cure" the participants, or even try to manipulate them.
} 
The participatory governance discussion is also going beyond the so-called "public and social acceptance" debate. This debate examines and develops arguments on factors of acceptance, or opposition from the perspective of local communities. However, the concept of public and social acceptance itself means rather some kind of passive attitude, such as acceptance towards something unchangeable, with outcomes in which the public has no influence anyway. It does not really consider active engagement as a part of decision-making processes, even though participation might become a crucial factor to increase acceptance (Batel et al., 2013). Perceptions of what are considered "successful" participatory processes and "sufficient" level of engagement may vary greatly between different types of stakeholders. Ideally, participation in environmental planning, such as the EIA procedure, is effective and the voices of local communities are taken into account. For example, suitable alternatives on how and where to implement different types of projects can be negotiated between industries and local communities. However, in reality there seems to be some kind of a "Decide-Announce-Defend" model that is still dominating the process and communication between different stakeholders, as it has been shown by studies of Battaglini et al. (2012), Komendantova et al. (2015), and Komendantova and Battaglini (2016).

\subsection{Research questions}

The main aim of this study is to understand stakeholders' perceptions on benefits and challenges of participatory environmental governance by studying different levels of public participation in industrial infrastructure project development. We hypothesise that these perceptions can vary considerably among different types of infrastructure projects and stakeholder types. Based on this hypothesis, we set two research questions:

1) How can reindeer herders participate in the planning and implementation of infrastructure projects, according to different types of stakeholders?

2) How do stakeholders' views on herders' levels of participation, as well as benefits and challenges of participatory processes, differ?

To address these questions, we conducted a qualitative empirical analysis of public participation in EIAs in Finland. We focused on two types of infrastructure projects by examining the EIA procedures of three mines and three wind farm projects that could significantly affect reindeer husbandry in Finland. We studied the perceptions of the EIA participation procedure of different types of stakeholders who have a role in the EIAs in Finland. 


\section{Methodology}

\subsection{Interviews}

The data is based on semi-structured, in-depth stakeholder interviews $(\mathrm{N}=31)$, see supplementary tables S1 and S2. First, stakeholder mapping was conducted by reviewing official EIA documents and websites. Stakeholders who played a central role in one or several different phases of the selected EIA cases were invited to the interviews by telephone or email. We also invited a few governmental EIA experts to gain general insights on the EIA procedure in Finland. An interview protocol was created to guide the interviews. The interviews were conducted in the period from December 2016 to January 2017 in Finland with stakeholders from industry (developers from the mining and wind farm companies), and government authorities (planners, policy makers, EIA experts, EIA coordinating bodies). In order to study the participation of local communities, we interviewed reindeer herders who are a relevant part of the local communities in northern Finland and are affected by the industrial infrastructure development. We interviewed the chiefs of six herding cooperatives, and an elderly herder from the biggest herding cooperative. In addition, we interviewed members of interest organisations like the governmental Herders' Association (Paliskuntain yhdistys) and an environmental NGO. The interview procedure took place mainly in the regions of Lapland and Northern Ostrobothnia. Supplementary table S1 presents the full list of organisations and types of interviewees. The interviews were conducted mainly in person, with the exception of one Skype interview. In addition, one person provided written responses to the interview questions by email. All interviews were conducted in the Finnish language by the corresponding author. The interviews were audio recorded with the permission of the interviewees. The audio data was fully transcribed and thereafter, coded and the content was analysed with $\mathrm{NVivo}^{\mathrm{TM}}$ qualitative analysis software, which was found very useful for handling large amount of textual data. The descriptive statistics were calculated, and graphs of the results were prepared in Microsoft Excel. Names of interviewees remain confidential: only the names of the organisations are presented as agreed with the interviewees.

\subsection{Case study}

\subsubsection{Selected projects}

We selected large-scale infrastructure projects that require an EIA and have had (or will likely have in the future) significant impacts on reindeer husbandry in Finland. Because we focused on large-scale mining and wind farm projects, the northernmost part of the reindeer husbandry area, i.e. the Sámi home area, was out of the scope of this study. This area is facing less land use pressure from these types of large-scale industrial activities than the other reindeer husbandry areas (Fig. 1). 
The selected projects are three mines, Kevitsa that operates in the municipality of Sodankylä, Suurikuusikko ("Kittilän kaivos" - the biggest gold mine in Europe) located in the Kittilä municipality, as well as Sokli that is under planning in the Savukoski municipality where the largest phosphorus deposit in Finland exists. All of these mine projects are located in the area "specially intended for reindeer husbandry" (see Fig. 1, respective numbers 15, 18, and 22 on the map). Furthermore, we selected three wind farm projects. The first project is KuolavaaraKeulakkopää: a wind farm located at the border of the municipalities of Kittilä and Sodankylä and also in the area "specifically intended for reindeer husbandry" (number 17 on the map). The second wind farm project is Joukhaisselkä-Tuore Kulvakkoselkä in the Sodankylä municipality, and the third is Maaninkavaara in Kuusamo municipality in Northern Ostrobothnia. Maaninkavaara is the largest offshore wind farm being planned in Finland. The latter two wind farms are located in the southern reindeer husbandry area (respectively numbers 19 and 37 on the map). 


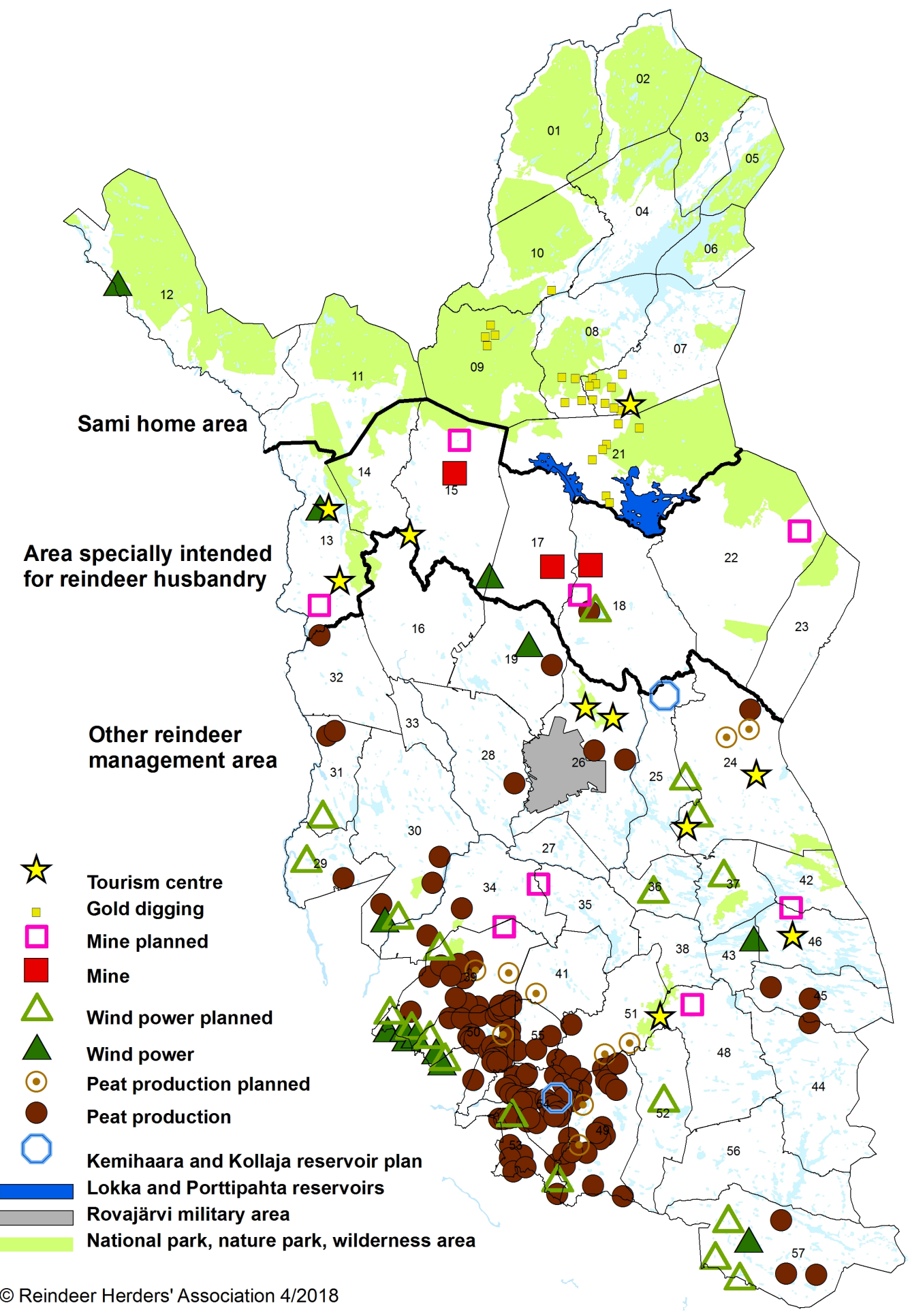

Fig. 1. Many types of industrial infrastructure projects change the traditional land use in the reindeer husbandry area. Reindeer (Rangifer tarandus tarandus) are semi-domesticated, in Finland mainly free-grazing herbivores. Map credit: Reindeer Herders' Association 4/2018. Reprinted with permission. 


\subsubsection{Selection criteria}

We used the following criteria to select the infrastructure projects for this study:

- Size: we only selected large-scale infrastructure projects which can have significant risks, as well as social, environmental, and economic impacts on reindeer husbandry.

- Actuality: we selected only projects which have gone through the Environmental Impact Assessment procedure (new project and/or project extension) within the last ten years.

We chose reindeer husbandry as an example of one the most important traditional livelihoods in Finland. Herders represent local communities in northern Finland and therefore they were invited to interviews in the framework of this study because they are already affected by the infrastructure projects or will likely be affected in the future (i.e. due to infrastructure projects that are under construction or development).

\subsubsection{Environmental Impact Assessment as an example of a public participation procedure}

In general, public participation in planning and decision-making can take place in different phases of an infrastructure project's life cycle: the initiation, planning, and implementation phases. In the EIA procedure in Finland, there are two phases when organising public hearings is mandatory: the first one takes place in the Assessment programme phase, when opinions and statements about the programme are given, and the second takes place in the Assessment report phase when opinions and statements about the report will be heard (see Koivurova et al., 2016, 35-53). We use the EIA procedure as a lens to analyse the cases of infrastructure projects and different types of participation in these projects across the different phases of the EIAs. Our data provides empirical evidence on public participation in EIAs and stakeholders' perceptions of herders' participation in the EIA procedure, while involving all the stakeholders who were actively engaged in the EIAs of the selected projects. Because our data were collected before the new EIA regulation in Finland came into force in May 2017, we discuss our results bearing this change in mind.

\subsection{Analytical methods}

First, we reviewed the literature and websites of the most relevant infrastructure projects in the reindeer husbandry area in Finland and selected two types of them; mines and wind farms. We studied the EIA procedures of the six selected projects. We empirically examined perceptions of benefits of public participation of reindeer herders in the EIA procedure, paying particular attention to which phases and levels of the EIAs participation are occurring or would be required. We evaluated the EIA procedure and public participation of herders from the point of view of the different types of stakeholders, taking into account their preferences and 
perceptions. We used a content analysis method (Neuendorf, 2016) to analyse the interview transcriptions. The content analysis was based upon three main variables:

Variable 1) Types of public participation: participation options that developers of wind farms and mines claim apply to reindeer herders during the EIA procedure; these are listed according to whether they are obligatory (based on EIA legislation) or non-obligatory (informal).

Variable 2) Perceptions of current public participation procedures on the EIA process: stakeholders' perceptions on herders' participation in EIAs of wind farms and mines, perceptions on benefits and challenges of public participation, and challenges and opportunities of participatory processes.

Variable 3) Level of participation: the analysis of different levels of participation was based upon the "Ladder of Citizen Participation" (Arnstein, 1969), which was applied to our case study. Based on the responses, we could identify certain level of participation according to Arnstein's three "ladders": "Citizen power," "Tokenism," and "Non-participation". Based on the response frequencies, we calculated the relative distribution of stakeholders' perceptions and we could identify which level of participation they mostly indicate (Fig. 2 in section 4.3).

\section{Results}

\subsection{Public participation types and types of communication between developers and} herders

\subsubsection{Formal (required by law)}

The interviewees stated that there are different types of public hearings; those that are organised during the EIA with all the local people, and public hearings for herders only. Government authorities must ensure that official negotiations with herders will take place according to the Reindeer Husbandry Act (848/1990, 53 §). Beyond the EIA, there are public hearings related to municipal plans, and public hearings and negotiations during the environmental permit procedures. During the EIA, the EIA coordinating body, the Centre for Economic Development, Transport, and the Environment (ELY) asks for official statements from stakeholders.

\subsubsection{Informal (voluntary for the developer)}

The interviewees stated that informal hearings organised by the developers, consultants and/or the coordinating authority (ELY) took place as small group hearings and roundtables, monitoring and steering groups, face-to-face meetings, phone and email communication, visits to project sites (such as family days for local people and open houses), and also map exercises 
between herders, developers and consultants. Written statements and opinions were given, and bilateral compensation negotiations and monitoring practices (e.g. the use of GPS collars for monitoring reindeer behaviour, provided by the developer) with the developer have been organised.

\subsection{Perceptions on participation procedure; benefits and challenges}

In the Table 1, we provide a summary of the stakeholders' views on participatory processes and on the EIA in particular. In the following sections, we also present direct quotations from the transcribed interview responses that refer to some of the benefits and challenges perceived by different stakeholders.

Table 1. Stakeholders' perceptions of the benefits and challenges of participatory processes.

\begin{tabular}{lll}
\hline & Benefits & Challenges \\
\hline $\begin{array}{l}\text { Consultants' } \\
\text { views }\end{array}$ & $\begin{array}{l}\text { Valuable information provided, } \\
\text { possibility for open discussion among } \\
\text { stakeholders, possible to meet people in } \\
\text { person, local knowledge can be integrated } \\
\text { into planning. }\end{array}$ & $\begin{array}{l}\text { Timing of meetings is challenging, meetings are } \\
\text { time consuming. The role of consultant is not } \\
\text { easy; need to deal with multiple issues and } \\
\text { remain neutral. For the public, it is sometimes } \\
\text { difficult to be aware of the topic. }\end{array}$ \\
& &
\end{tabular}

\begin{tabular}{ll}
\hline Government & Information sharing and awareness \\
authorities' (ELY) & raising beneficial, the impacts will be \\
views & evaluated in-depth; opportunities to \\
& participate in planning, potential gaps in \\
& the plans can be identified.
\end{tabular}
Media can negatively affect EIA process if wrong information provided. Those having extreme opinions and the public who do not understand reindeer husbandry should not participate. For the public, the EIA process can be too complex; unclear when opinions can be given, meetings organized in wrong time for herders.

\begin{tabular}{ll}
\hline $\begin{array}{l}\text { Developers' } \\
\text { (industry) views }\end{array}$ & $\begin{array}{l}\text { Gain information from the public also for } \\
\text { further planning, increase social } \\
\text { acceptance of projects and build trust, } \\
\text { maintain good image of the company, } \\
\text { increase understanding of different views. }\end{array}$
\end{tabular}

Media presence can complicate the EIA process, because sometimes it gives wrong information. Only regular, frequent and open dialogue leads to good results. Persons with strong personal attitudes and ideology problematic in public hearings.

\begin{tabular}{ll}
\hline Herders' views & $\begin{array}{l}\text { Updates on infrastructure projects to } \\
\text { understand the scale of projects, } \\
\text { possibility to provide feedback. } \\
\text { Participatory processes reduce conflicts. } \\
\text { Herders can also share information with } \\
\text { the developer, who does not necessarily } \\
\text { know much about reindeer husbandry. }\end{array}$ \\
& EIA obligates to engage: developer and \\
& herder must negotiate because the EIA is \\
Views of & a formal setting.
\end{tabular}

Meeting fatigue if too many public hearings. Developers do not have enough (technical) information in the early phase of planning. EIA reports are too long. Communication problems: language barriers, arrogant ways of presenting, and lack of knowledge on reindeer management.
If the developer does not engage herders early enough, the herders do not have real influence on planning. It is also challenging for herders to understand all information presented by the developer, such as very technical details on chemical processes of mining, etc.

\begin{tabular}{ll}
\hline $\begin{array}{l}\text { Views of } \\
\text { environmental }\end{array}$ & $\begin{array}{l}\text { A lot of information can be gained, which } \\
\text { otherwise is not available. Some } \\
\text { developers are considering opinions of }\end{array}$ \\
NGO & $\begin{array}{l}\text { local people, which is positive, but this is } \\
\text { not always the case. }\end{array}$
\end{tabular}

Success of participatory processes depends a lot on personality of the one who leads the meetings, for example consultants: ability to listen the public and not dominate the discussion. 
Views of other governmental authorities
Gain social acceptance, more information and better understanding of objectives and needs of different types of stakeholders.
Too many participatory processes can be exhausting for the public. Media can affect the developer's image and attitudes of the public. Developer's unprofessional behaviour can destroy trust. Lack of sufficient details of the project can cause insecurity and dissatisfaction among the public. Timing of meetings is sometimes wrong. More understanding on reindeer husbandry is needed.

\begin{tabular}{lll}
\hline $\begin{array}{l}\text { Views of the } \\
\text { ministry }\end{array}$ & $\begin{array}{l}\text { EIA informs the participants in the very } \\
\text { early stage of planning and the public has } \\
\text { the right to know about planned projects. } \\
\text { This is the value of EIA. }\end{array}$ & $\begin{array}{l}\text { Sometimes the public feels that if a project is } \\
\text { going to be implemented despite of the protests, } \\
\text { the participatory process was not successful. }\end{array}$ \\
\hline
\end{tabular}

Participation in EIA is perceived at the ELY and at the ministerial level as a real planning opportunity for the public. According to EIA coordinators of ELY, participation procedures have become better. For example, the integration of herders into planning, as well as the expertise of consultants, have improved during the last two decades. The Herders' Association played an important role in improving and increasing participation and raising awareness on the relevance of herding. But there are also gaps in knowledge regarding how to engage local communities for participation. For example, the possibilities for herders to participate vary depending upon the herding practices taking place and the season. A government authority, states that:

"At the national level the relevance of reindeer husbandry is not well understood. I do not mean in financial or economic terms, but I mean the entire process. One of the barriers is the organization of meetings at inappropriate times, such as during the gathering of reindeer for the round-up. The developers do not understand specifics of reindeer husbandry. They do not understand that herders spend two weeks in the field and cannot come. It is necessary to understand herders' position and the practices of their livelihood to be able to 'speak the same language' with them." (Government authority, other)

Ways to reduce land use conflicts, such as those driven by fragmentation and loss of pastures due to industrial development, and debates on land use conflicts between different parties must be considered. One developer states that participation is of the utmost importance to creating good contacts with local people and building trust whenever possible, in order to discuss alternative ways to implement infrastructure deployment and reduce these conflicts:

"You have to be present there, discuss with local people, take them into account as humans. The herders are not necessarily on an opposite side but in practice they are your collaborators. In this way you will not end up having conflict situation but follow the same lines. Both parties have the same objective: that this project can be started well and also that this [traditional] livelihood remains viable." (Developer) 
It is considered beneficial if developers and consultants are familiar with the local conditions and have local knowledge, when organising the hearings. As one developer says,

“...you have to be able to speak their 'dialect' and understand them a bit...on that basis we have been building trust [with local communities]". (Developer)

However, some meeting fatigue has also been felt throughout the participatory procedures. This claim was made by consultants and herders who think that there are too many similar processes (EIA, municipal plans, permission procedures etc.) that put time constraints on participants. Some herders wish to be more actively involved in the EIA process, to be consulted regularly as experts in particular, and to have the opportunity to contribute to the EIA assessment reports more directly:

"Well, why on earth are the local herding cooperative members not considered as experts, similarly to experts in the EIA, whose statements are reported openly in the way they argue? Why can this not be done? Because then, after reading the EIA report, the coordinating government authority could see the herding cooperative's real point of view, and not as the consultant has reported it." (Herder)

Developers think that the local knowledge, attitude, and "language," such as the presentation style the presenter uses in hearings, play a very important role in the success of participatory processes, to gain the respect of the public. Thus, in an ideal case, consultants, for instance, could be important knowledge brokers. A developer also points out that:

"You must choose consultants who are capable of negotiating with various types of livelihoods and businesses. It is extremely important to choose people who can understand different viewpoints. It also makes things easier and brings stakeholders closer together." (Developer)

This is in line with the opinion of a government authority member, who states that:

“...the persons that have been selected [to lead the meetings with the public] very much influence the outcome of small group meetings. After all, in small communities, things will be personalised anyway." (Government authority, other)

The government authority (ELY) points out that success depends on how consultants have studied and estimated the impacts, but also on their personality and expertise. Their local knowledge in particular is important because it creates trust. Thus, participation efficiency is to some extent dependent on persons; how they are selected and what kind of tasks they have. Ultimately these factors affect whose voices will finally be heard. Herders hope for even more 
support from the Herders' Association for participatory processes and a more active role on the part of developers to keep regular contact with herders throughout the project life cycle.

\subsection{Perceptions of the level of participation and fairness of participation procedure}

Although some consultants think that the EIA provides real participation opportunities and that the public can influence planning and decision-making in the process, overall the responses belong to the category of "Tokenism". The application of the Arnstein's "ladder" showed that the views of the government authorities from ELY on public participation are quite diverse (Fig. 2). One thought that herders' voices are heard, but that these are not taken into account in reaching a compromise ("Tokenism"). One claimed that there are no real possibilities to exert influence. For example, the different project alternatives cannot be influenced because these are already fixed before the participation procedure starts ("Non-participation"). The example below shows that it is problematic if none of the given alternatives consider any of the public needs, such as those of herders, but the given alternatives only "force" them to make a choice between several harmful options:

"If we think about the EIA procedure as such, it is kind of odd in a way. It is the developer who selects the alternatives based on their own interests and the alternatives are being circulated in the EIA process, until the process ends in a statement of the coordinating body. But throughout the process there might not have been one single alternative that would be reasonable from the perspective of local people." (Government authority ELY)

Some government authorities from ELY think that participation is truly influencing planning. Namely, that active discussions in public hearings enable the concerns of herders on impacts to be included into considerations (see also Table 1). Examples of "Citizen power" can be identified in the interview responses. One example shows that knowledge of specific details of reindeer movements has been taken into account: the originally planned location of power transmission lines for wind farms was changed to an alternative routing that reduces the impacts on reindeer herding:

"For example, location of power transmission lines; in the EIA, entirely new implementation options have appeared. I cannot say whether these [new alternatives] have been solely based on the perspective of reindeer herding but herders have had an opportunity to influence the decision [on the implementation options]." (Government authority ELY)

The developers think that participation can influence the planning process. They give examples such as that in one case herders' complaints led to one mineral deposit not being extracted. 
Another developer stated that without herders' knowledge the developer could not operate in the area because important practical details on herding would be missing, such as where the places are that the developer should avoid when planning the infrastructure for the area, e.g. how reindeer move in the area, where the calving places are and many other important details (see also Table 1). Although quite a few examples show that herders have been consulted, as they should be, it still does not mean that their voices have truly been taken into consideration in planning and cannot be categorised as "Citizen power," but rather "Tokenism:"

"The reindeer herding small group meetings took place often. In these meetings the situation was broadly discussed, particularly from the viewpoints of reindeer herding. Not only the local herder representatives were present but also representatives from other herding cooperatives and people from the Herders' Association. They gave us, developers, a very detailed assessment and relatively high-quality maps to see how reindeer move [in the area where the project is planned], where they calve, and graze in spring, winter etc." (Developer)

Regarding potential impacts, another developer highlighted the importance of participatory processes and networking with stakeholders within the EIAs and beyond, to also gain knowledge and understanding on risk and impacts from herders, as the developer stated that:

"It is very difficult to know what kinds of impacts the planned project will bring about. The only experts considering reindeer husbandry are the herders themselves. The others can only guess." (Developer)

Among herders, the perceptions on participation levels were rather polarised. Quite a few herders think that it is possible to influence decisions via good communication and a good relationship with developers. The example of the mineral deposit excluded from the extraction plans for the time being and relocation of a power transmission line in the case of a wind farm were also mentioned. This is how herders themselves described what we could identify as "Citizen power":

"... a new mineral deposit was found at about $2 \mathrm{~km}$ [depth] under the current deposit. It is $15 \mathrm{~km}$ from here. It is a "satellite" ore and they tried to include it in the same EIA but I told them at some point to leave it out [of the plan] ..."

"We actually have good communication with the mining company so that if I need something, I go directly to the security and tell them that I am going upstairs directly to the CEO."

"...they [the developers] have to consider, that while preparing an EIA it is better to take into account [herders' voices] in the very beginning that we do not have to 
return it [the assessment report] from 'above'."

(Herder, on mines)

"Well it was the [one particular] power transmission line they wanted to build. We completely rejected that. It would have been so wide that use of our helicopter at the main fence [during round-ups] was hindered. We completely rejected that [option] and it was removed [from the plan] and they built a more expensive line in another location ..."

(Herder, on wind farms)

The Herders' Association mentioned that especially if the herders are invited to the EIA process too late, they do not have any real influence on the decision-making (see also Table 1). Those herders, who feel that they have no influence, provided a few examples; negotiations with a sufficient amount of details could not be organised, and they felt that the developer hears the herders but does not "listen to" them. Some feel that the developer does not want to consider herders' suggestions due to the lack of financial resources to be able to consider other implementation options, as this example shows:

"If it [a wind farm] was built in this corner [drawing a map of the area] it would not cause so much harm for reindeer. Reindeer are such territory dependent animals that they do not move away if they feel well and even if we try to move them they return... so we asked the developer whether it is possible to reduce the size of the wind farm to keep this particular area for our reindeer, but they could not afford it." (Herder, on wind farms)

To summarise the above, perceptions of the level of herders' participation in planning and decision-making are diverse, as Fig. 2 illustrates. However, the majority of responses show that participation in many of the projects is still at the level of "Tokenism" even though some examples of "Citizen power" can be found. 


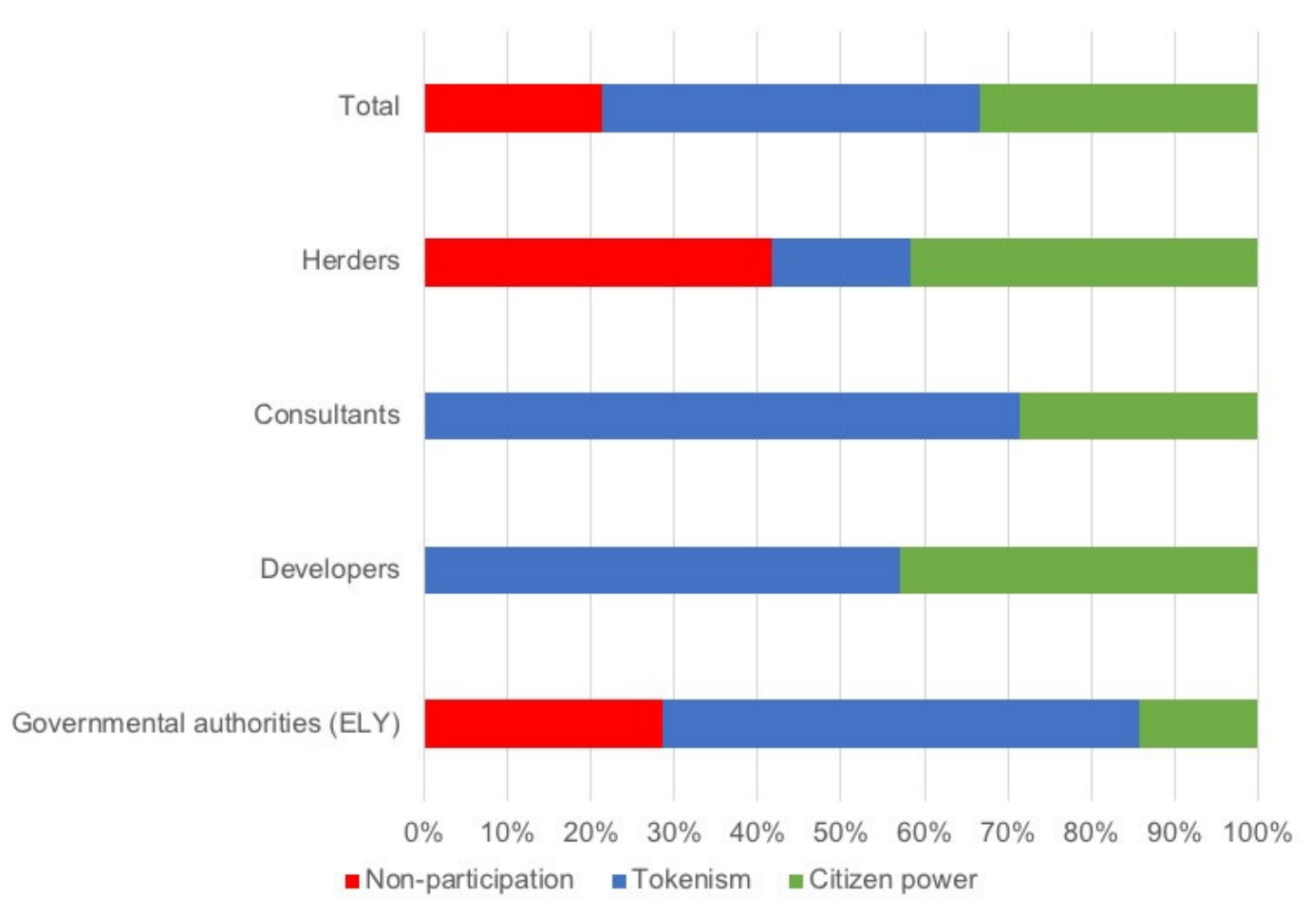

Fig. 2. Relative distribution of stakeholders' responses (frequencies) to the level of herders' participation in EIA, categorised into Arnstein's Ladder of Citizen Participation. We were able to identify one to three aspects of each interviewee of these four types of stakeholders' groups to study the perceptions on the level of participation.

According to the interview responses, a good start for participatory processes, such as creating early contacts, is not enough because building long-term trust requires sustained, reciprocal communication with the public. An example of this is if the developer sells the project or if the company (developer) does not know enough details of the case, such as challenges with herding, social impacts, or long-term impacts. This becomes particularly difficult if compensation for harm that has been caused is required to reduce the (economic) losses. There seems to be a gap in the legislative framework regarding the issue of project ownership in infrastructure projects. Quite often the developer sells the project right after the EIA procedure. Responsibilities will not be automatically transferred to the new owner, so some legal steering mechanisms is needed in these cases, as stated by the developer, consultant, government authority, and herder. A consultant clarifies the main problem concisely:

"Actually, the core problem or question is how to make sure that the developer of the project takes responsibility of the potential impacts stated in the EIA or municipal plan, and ... how compensation solutions can be achieved. Because after all it is the developer from the company who makes an agreement [contract on compensation] with herders' cooperative; these are bilateral agreements. If one party leaves, the agreement does not exist anymore ..." (Consultant) 
Table 2 presents more issues related to project ownership changes that need better attention in EIAs. We would like to highlight these because they are related to social and environmental responsibility concerning planning, implementing, and monitoring infrastructure projects also beyond the EIAs. Although the herders hope for more communication and responsibility from the developers in planning the project alternatives in the early stage of the projects, Table 2 shows that also monitoring potential impacts after the implementation and closure of project is crucial. The results indicate that the current legal framework is not optimal because there are no legal requirements for long-term monitoring, no framework for obligatory compensation agreements, and no obligations for new developers to keep in touch with herders.

Table 2. Issues that should be better addressed in the EIAs in Finland. Based on the interview responses.

\begin{tabular}{|c|c|c|}
\hline Stakeholder & Issues & Example \\
\hline Consultant & $\begin{array}{l}\text { Land tenure } \\
\text { issues }\end{array}$ & $\begin{array}{l}\text { It is more difficult for developers to operate when there } \\
\text { several land owners instead of the only one owner, } \\
\text { such as the state }\end{array}$ \\
\hline $\begin{array}{l}\text { Governmental } \\
\text { authority } \\
\text { (ELY) }\end{array}$ & $\begin{array}{l}\text { Social and } \\
\text { environmental } \\
\text { responsibility }\end{array}$ & $\begin{array}{l}\text { Legal framework not yet optimal to transform } \\
\text { responsibility to a new owner if the project is sold after } \\
\text { the EIA }\end{array}$ \\
\hline $\begin{array}{l}\text { Governmental } \\
\text { authority } \\
\text { (ELY) }\end{array}$ & $\begin{array}{l}\text { Communication } \\
\text { gaps }\end{array}$ & $\begin{array}{l}\text { Good communication with herders can be lost in the } \\
\text { case when a new developer takes the project over }\end{array}$ \\
\hline $\begin{array}{l}\text { Developer } \\
\text { (industry) }\end{array}$ & $\begin{array}{l}\text { Communication } \\
\text { responsibility }\end{array}$ & $\begin{array}{l}\text { It is up to the new developer to communicate with the } \\
\text { public after the EIA }\end{array}$ \\
\hline $\begin{array}{l}\text { Developer } \\
\text { (industry) }\end{array}$ & $\begin{array}{l}\text { Monitoring } \\
\text { responsibility }\end{array}$ & $\begin{array}{l}\text { It is up to the new developer to implement monitoring } \\
\text { practices }\end{array}$ \\
\hline Herder & $\begin{array}{l}\text { Communication } \\
\text { gaps }\end{array}$ & Language barriers with foreign developers \\
\hline Herder & $\begin{array}{l}\text { Compensation } \\
\text { responsibility }\end{array}$ & $\begin{array}{l}\text { Responsibilities for compensation are not clear, written } \\
\text { agreements with herding cooperatives are needed }\end{array}$ \\
\hline $\begin{array}{l}\text { Herders' } \\
\text { Association }\end{array}$ & $\begin{array}{l}\text { Compensation } \\
\text { responsibility }\end{array}$ & Written, formal compensation agreements are needed \\
\hline $\begin{array}{l}\text { Governmental } \\
\text { authority } \\
\text { (other) }\end{array}$ & $\begin{array}{l}\text { Communication } \\
\text { responsibility }\end{array}$ & $\begin{array}{l}\text { Developers should make sure that communication with } \\
\text { the herders after the EIA continues even if the project } \\
\text { will be sold }\end{array}$ \\
\hline $\begin{array}{l}\text { Governmental } \\
\text { authority } \\
\text { (other) }\end{array}$ & $\begin{array}{l}\text { Monitoring } \\
\text { responsibility }\end{array}$ & $\begin{array}{l}\text { New owner can introduce new types of measures } \\
\text { which have not been included in the EIA }\end{array}$ \\
\hline $\begin{array}{l}\text { Governmental } \\
\text { authority } \\
\text { (other) }\end{array}$ & $\begin{array}{l}\text { Compensation } \\
\text { responsibility }\end{array}$ & $\begin{array}{l}\text { The whole social process will not be transferred to the } \\
\text { new owner together with the project. Bilateral } \\
\text { compensation agreements can be negotiated but this is } \\
\text { not yet obligatory }\end{array}$ \\
\hline $\begin{array}{l}\text { Governmental } \\
\text { authority } \\
\text { (other) }\end{array}$ & $\begin{array}{l}\text { Social and } \\
\text { environmental } \\
\text { responsibility }\end{array}$ & $\begin{array}{l}\text { The currently loose legal framework gives the } \\
\text { responsibility to the new owner to take social and } \\
\text { environmental responsibility for the project }\end{array}$ \\
\hline
\end{tabular}




\section{Discussion}

Sustainable development and transition pathways for the Arctic region require the collaboration of multiple actors on how to equally govern risks, share responsibilities, and adapt to the inevitable changes that the Arctic is facing. We used the EIA as a lens to study participatory environmental governance of the infrastructure projects of mines and wind farms in the reindeer husbandry area in Finland because the increasing industrial development is affecting the preconditions for traditional Arctic livelihoods. In particular, we studied public participation in the EIA, but we wanted to identify potential gaps in participatory environmental governance also more broadly. The empirical examples of the EIA processes in this study show benefits and challenges of participatory governance and public participation process regarding the EIA.

In this study, the stakeholders were asked how they perceive herders ' participation possibilities and degree of participation. There have been few empirical studies, which have considered the viewpoints of different types of stakeholders on the land use issues of mines and wind farms with a focus on reindeer husbandry. Our results show differences in stakeholders' perceptions of reindeer herders' possibilities to participate in the EIAs, and some similarities as well. This becomes evident when looking into the different levels of participation in the EIAs based on stakeholders' perceptions and experiences in the EIAs of mining and wind farm projects.

In our study, "Tokenism" was identified as the most common level of herders' participation in the EIAs: this means herders are well-consulted, but their participation does not necessarily affect decision-making, which seems to be the usual case in public participation (e.g., Saarikoski et al., 2010). We also found that different goals and objectives of participation between different types of stakeholders, lack of communication, miscommunication, and lack of knowledge of the involved parties, as well as heterogeneous (risk) perceptions can complicate environmental planning. Data gaps also exist because some of the developers' data is confidential and cannot be published, or some technical details are simply not available, for example, the developer does not have long-term data. Engaging herders in regular informal meetings are considered very useful among all stakeholders, and these can be organised within the EIAs, during the municipal planning process, or beyond these on a voluntary basis.

The objectives of participatory processes vary between different types of stakeholders. Consultants find it particularly beneficial that participatory processes enable people to meet in person and to gain local knowledge to be integrated into environmental planning. For herders it is important to have the opportunity of being in direct and early contact with developers. In this manner, trust can be built. For herders the main objective of participation is to gain 
information and updates on the projects planned in the reindeer husbandry area. They also see participation not only as a way to share information on herding and provide feedback, but also as a way to reduce conflicts that might otherwise appear if too little information on the relevance of herding was available for developers. According to government authorities, the main objectives of participatory processes are to get an in-depth evaluation of potential impacts, share information between stakeholders, and gain social acceptance for projects. Developers' objectives are to try to maintain a good image of their companies and receive information from herders for planning.

It is positive that nowadays developers are becoming more active in engaging herders. According to our results, there are developers who feel that it is important to understand the different viewpoints and build trust via participatory processes. For some companies, it is selfevident that they should consult local communities in the very early phases of planning. Companies with previous experience with local and indigenous communities especially were considered to have more awareness and understanding of local peoples' needs. This is in line with Koivurova et al. (2016) who state that the private sector is actually driving the improvement of the EIA due to higher environmental standards and practices in local communities that are not necessarily required by law. According to the governmental authorities there are improvements in terms of the level of knowledge of both the developers and consultants, in particular in the case of mine projects. This is also in line with the findings of Koivurova and colleagues (2016) who consider that reindeer husbandry in Finland is well addressed in industrial infrastructure development projects. However, compared to mining companies, we found that wind farm companies have not engaged herders as actively beyond formal hearings, especially to maintain more sustained communication once an EIA has been accepted and implementation begins to take place. It seems to be very much dependent on the developers' willingness, motivation and resources to engage local communities and hire consultants who have sufficient knowledge of herding and local knowledge. According to our findings it is beneficial to include a local person in the preparation of the EIA documents because a higher level of local knowledge can build trust among stakeholders and a person with local knowledge leading public hearings can be a knowledge broker.

Some herders believe in participation' benefits, whereas others mentioned having some negative experiences in participatory processes. This appears to vary considerably from project to project. The perceptions of herders on the degree of participation were quite polarised. In general, the herders feel that they are contacted early on, but do not have enough influence on decision-making or planning. The developers' responses varied between "Tokenism" and "Citizen power"; the developers think that herders are well consulted and engaged in EIAs 
because they are a good source of information which is valuable for the planning of the operations of the projects. However, herders argue that they are not considered as experts although they are the ones who understand this livelihood and the potential social, environmental and economic impacts of development projects on reindeer husbandry better than anybody else. Koivurova and colleagues (2016) have found that developers do not have enough resources to analyse all project implementation alternatives and little guidance on how to decide on the alternatives in the first place. We argue that collaboration with herders can provide them with expertise and practitioners' knowledge, and therefore herders should be involved in co-designing the different project implementation alternatives with the developers. Herders' perceptions of successful participation come from examples where herders were able to negotiate the relocation of a power transmission line for a wind farm and change the mine company's plan to utilise a satellite deposit. Negative experiences of participation were related to communication deficits, such as unclear meeting objectives, which led to mistrust among herders. Meeting outcomes have sometimes been perceived as unclear by herders, as the language of the developers is too technical and social impacts are not sufficiently presented in the EIA documents. Herders consider it important to be able to present their concerns and needs and to report potentially negative impacts directly to developers throughout the life of a project.

The government authorities also mention challenges of participatory processes, including the lack of knowledge on reindeer husbandry, and the role of the media that sometimes shows biased accounts of actual risks and impacts which affects peoples' attitudes. Herders wish that communication starts before the EIA process to avoid misunderstandings and rumours that can otherwise be spread, such as via media which has been considered problematic also in other studies (e.g., Enríquez-de-Salamanca, 2018). Some meeting fatigue has been experienced because the municipal planning and environmental permit procedures also include public hearings, and these can take place in parallel with the EIA hearings if several infrastructure projects are planned in the same area. A new EIA legislation that came into force in May 2017 in Finland, after our data collection, aims to improve the EIA process by combining some of the public hearing procedures from the EIA and municipal planning processes.

In many countries, the quality of the EIA varies considerably, and social and cumulative impacts are not sufficiently covered (Koivurova et al., 2016; Stammler, 2014; Wilson, 2017). The new EIA legislation will also require that the quality of the assessments improves; higher level of expertise is available, and more attention is paid to cumulative impacts. Our empirical results also confirmed that in particular these improvements are urgently needed and revealed how important it is to understand the different objectives and perceptions of stakeholders and 
especially the needs of local communities to enhance the EIA but also participatory environmental governance more broadly.

\section{Concluding remarks}

There are a number of ways and multiple dimensions on how to evaluate effectiveness of environmental planning procedures such as the EIA and participatory environmental governance as a whole. In order to understand how different land users' interests could be reconciled and how compromises in environmental planning outcomes could be achieved via public participation, more understanding of the heterogeneous perceptions of benefits and challenges and different stakeholders' needs is needed. This study fills this gap.

Based on our results, so far, reindeer herders' participation in the EIA in Finland is still characterised by "Tokenism." This means that local people are consulted, but they still do not have enough decision-making power, and if they do, it appears only in certain phases of the project planning within the EIAs, but not throughout the life of the project, such as in the longterm monitoring. These are important things that should be taken into account when considering how to improve participatory processes and stakeholders' interaction within the EIA and in participatory environmental governance in general.

We found that social impacts have not been assessed in detail, and not enough attention has been paid to cumulative impacts although they were considered as the most important risk drivers regarding reindeer husbandry, according to all types of stakeholders. A broader understanding of cumulative impacts is needed because otherwise the size and scale of the project and its impacts can be underestimated. The legal framework has not been optimal for making sure the outcomes of participatory processes in the EIAs will be applied to project implementation and monitoring or making sure that the social and environmental responsibility of the developer remains even if the project will be sold after the EIA. The latter is particularly difficult in terms of compensation and long-term monitoring that would be often required. Indeed, all the stakeholders would like to see a better framework for monitoring and compensation schemes because monitored data is not always available, or it is fragmented. Our results also reveal gaps in the legislative framework regarding compensation schemes. Equal and fair compensation schemes are considered crucial for herders to be able to overcome some of the monetary losses.

In case of projects affecting reindeer husbandry, considering herders as experts in the EIA need developers' attention and governmental authorities' consideration, but obviously better 
regulatory steering to make it possible. Furthermore, developers should understand reindeer husbandry better - its importance, needs, and the preconditions this livelihood needs to remain viable. In northern Finland reindeer husbandry has kept remote areas inhabited for centuries. This study revealed challenges of participatory environmental governance and demonstrated some of these by the empirical examples of public participation in the EIA. Conflicts arise when a traditional nature-based livelihood comes against relatively short-term economic activities such as wind farms and mines. Reconciliation of different land users interest is definitely not easy but learning from participatory procedures such as the EIA can improve understanding of perceptions and objectives of different types of stakeholders, but also reasons why land use conflicts sometimes appear and how compromises can be achieved.

Since the EIA is a planning tool, we argue that it could be used much more efficiently as a negotiation and information sharing "laboratory" if representatives of traditional livelihoods, in our case herders, could be considered as experts. Since cumulative impacts should be better monitored and compensation for damage negotiated, more calculations would be needed to be able to compare the economic benefits of industrial activities in these areas with the social, cultural and economic benefits of herding in the long-term. However, it is questionable whether a loss of livelihood can be compensated at all or whether a culture can be or should be considered as a commodity.

Long-term sustainable environmental development and protection of culturally valuable socialecological systems would also need new regulatory steering mechanisms because the current mechanisms cannot fully capture these and therefore improvement of the EIA procedure to standardize the procedures would be needed. Previous studies as well as the findings our study clearly show that cumulative impacts and social impacts are very often missing in the EIAs, and responsibilities for monitoring impacts in the long term are not clear. Future studies should analyze these more broadly by looking into, for example, other Arctic countries.

\section{Acknowledgements}

The Postdoctoral Program of the International Institute for Applied Systems Analysis (IIASA), Austria supported this research. We would like to thank all stakeholders who contributed their time and expertise during the interviews. We are also grateful for the additional support of the Nordic Centre of Excellence in Arctic Research 'Reindeer Husbandry in a Globalizing North' (ReiGN) funded by NordForsk. Special thanks to two anonymous reviewers and Dr. Heli Saarikoski (Finnish Environment Institute SYKE) for their very constructive and helpful comments that greatly contributed to improving the final version of the paper, and Ms. Melissa Evans who provided English language support. 


\section{References}

Anttonen, M., Kumpula, J., Colpaert, A., 2011. Range selection by semi-domesticated reindeer (Rangifer tarandus tarandus) in relation to infrastructure and human activity in the boreal forest environment, northern Finland. Arctic, 1-14.

Arnstein, S. R., 1969. A ladder of citizen participation. J. Am. I. Planners 35, 216-224.

Batel, S., Devine-Wright, P., Tangeland, T., 2013. Social acceptance of low carbon energy and associated infrastructures: A critical discussion. Energ. Policy 58, 1-5.

Battaglini, A., Komendantova, N., Brtnik, P., Patt, A., 2012. Perception of barriers for expansion of electricity grids in the European Union. Energ. Policy 47, 254-259.

Bautista, S., Llovet, J., Ocampo-Melgar, A., Vilagrosa, A., Mayor, Á. G., Murias, C., Ramón Vallejo, V., Orr, B. J., 2017. Integrating knowledge exchange and the assessment of dryland management alternatives-A learning-centered participatory approach. J. Environ. Manage. $195,35-45$.

Coelho, V., Favareto, A., 2011. Participatory governance and development: In search of a causal nexus. Geogr. Compass. 5, 641-654.

Colman, J. E., Eftestøl, S., Tsegaye, D., Flydal, K., Mysterud, A., 2012. Is a wind-power plant acting as a barrier for reindeer Rangifer tarandus tarandus movements? Wildlife Biol. 18, 439-445.

Dale, B., Bay-Larsen, I., Skorstad, B., 2018. The Will to Drill-Mining in Arctic Communities. Springer, Cham.

Enríquez-de-Salamanca, Á., 2018. Stakeholders' manipulation of Environmental Impact Assessment. Environ. Impact Assess. 68, 10-18.

Flydal, K., Eftestøl, S., Reimers, E., Colman, J. E., 2004. Effects of wind turbines on area use and behaviour of semi-domestic reindeer in enclosures. Rangifer 24, 55-66.

Flydal, K., Korslund, L., Reimers, E., Johansen, F., Colman, J. E., 2009. Effects of power lines on area use and behaviour of semi-domestic reindeer in enclosures. Int. J. Ecol. https://doi:10.1155/2009/340953

Forbes, B. C., 2007. Equity, vulnerability and resilience in social-ecological systems: a contemporary example from the Russian Arctic, in Wilkinson, R.C., Freudenburg, W.R. (Eds.) Equity and the Environment. Emerald Group Publishing Limited, Bradford, pp. 203236.

Ford, J. D., Smit, B., Wandel, J., Allurut, M., Shappa, K., Ittusarjuat, H., Qrunnut, K., 2008. Climate change in the Arctic: current and future vulnerability in two Inuit communities in Canada. Geogr. J. 174, 45-62.

Groves, C., Munday, M., Yakovleva, N., 2013. Fighting the pipe: neoliberal governance and barriers to effective community participation in energy infrastructure planning. Environ. Plan. C Gov. Policy 31, 340-356

Heikkinen, H. I., Kasanen, M., Lépy, É. 2012. Resilience, vulnerability and adaptation in reindeer herding communities in the Finnish-Swedish border area. Nordia Geog. Publ. 41, 107-121. 
Helle, T. P., Jaakkola, L. M., 2008. Transitions in herd management of semi-domesticated reindeer in northern Finland, in: Ann. Zool. Fennici, pp. 81-101, Finnish Zoological and Botanical Publishing.

Herrmann, T. M., Sandström, P., Granqvist, K., D’Astous, N., Vannar, J., Asselin, H., Saganash, N, Mameamskum, J., Guanish, G., Loon, J.-B., Cuciurean, R., 2014. Effects of mining on reindeer/caribou populations and indigenous livelihoods: community-based monitoring by Sami reindeer herders in Sweden and First Nations in Canada. Polar J. 28-51.

Kearney, J., Berkes, F., Charles, A., Pinkerton, E., Wiber, M., 2007. The role of participatory governance and community-based management in integrated coastal and ocean management in Canada. Coast. Manage. 35, 79-104.

Koivurova, T., Lesser, P., Bickford, S., Kankaanpää, P., Nenasheva, M., 2016. Environmental Impact Assessment in the Arctic: A Guide to Best Practice. Edward Elgar Publishing, Cheltenham.

Komendantova, N., Vocciante, M., Battaglini, A., 2015. Can the BestGrid process improve stakeholder involvement in electricity transmission projects? Energies 8, 9407-9433.

Komendantova, N., Battaglini, A., 2016. Beyond Decide-Announce-Defend (DAD) and Notin-My-Backyard (NIMBY) models? Addressing the social and public acceptance of electric transmission lines in Germany. Energy Res. Soc. Sci. 22, 224-231.

Kumpula, T., Pajunen, A., Kaarlejärvi, E., Forbes, B. C., Stammler, F., 2011. Land use and land cover change in Arctic Russia: Ecological and social implications of industrial development. Global Environ. Change 21, 550-562.

Kumpula, J., Kurkilahti, M., Helle, T., Colpaert, A., 2014. Both reindeer management and several other land use factors explain the reduction in ground lichens (Cladonia spp.) in pastures grazed by semi-domesticated reindeer in Finland. Reg. Env. Change, 14, 541-559.

Leppänen, J. J., Weckström, J., Korhola, A., 2017. Multiple mining impacts induce widespread changes in ecosystem dynamics in a boreal lake. Sci. Rep.-UK 7, 10581.

Loomis, J. J., Dziedzic, M. (2018). Evaluating EIA systems' effectiveness: a state of the art. Environ. Impact Assess. 68, 29-37.

Ministry of Environment (2013). Environmental Impact Assessment. http://www.ymparisto.fi/en-

US/Forms_permits and environmental_impact assessment/Environmental_impact assessme nt Last access 30 May, 2018.

Northey, S. A., Mudd, G. M., Werner, T. T., Jowitt, S. M., Haque, N., Yellishetty, M., Weng, Z., 2017. The exposure of global base metal resources to water criticality, scarcity and climate change. Global Environ. Change 44, 109-124.

Neuendorf, K. A., 2016. The Content Analysis Guidebook. Sage, Thousand Oaks, California.

O'Faircheallaigh, C., 2010. Public participation and environmental impact assessment: Purposes, implications, and lessons for public policy making. Environ. Impact Assess. 30, 1927.

Oskal, A., Turi, J. M., Mathiesen, S. D., Burgess, P., 2009. Ealát. Reindeer Herders' Voice: Reindeer herding, traditional knowledge and adaptation to climate change and loss of grazing 
land. Arctic Council's Sustainable Development Working Group. https://oaarchive.arcticcouncil.org/handle/11374/47 Last access 30 May, 2018.

Rees, W. G., Stammler, F. M., Danks, F. S., Vitebsky, P., 2008. Vulnerability of European reindeer husbandry to global change. Climatic Change 87, 199-217.

Renn, O., 2008. Copying with Uncertainty in A Complex World. Earthscan, London.

Ross, S. G., 2018. From consultation to consent: A comparative analysis of Arctic states, in: O'Donnell, B., Gruenig, M., Riedel, A. (Eds.), Arctic Summer College Yearbook, pp. 9-20.

Saarikoski, H., Tikkanen, J., Leskinen, L. A. 2010. Public participation in practiceAssessing public participation in the preparation of regional forest programs in Northern Finland. Forest Policy Econ 12, 349-356.

Saarni, K., Nieminen, M., 2011. Tukipolitiikan vaikutukset Suomen poronhoitoon. Riista- ja kalatalous. Tutkimuksia ja selvityksiä 10/2011. Riista- ja kalatalouden tutkimuslaitos, Helsinki.

http://jukuri.luke.fi/bitstream/handle/10024/530739/rkts2011_10.pdf?sequence=1\&isAllowed =y Last access 30 May, 2018.

Skarin, A., Nellemann, C., Rönnegård, L., Sandström, P., Lundqvist, H., 2015. Wind farm construction impacts reindeer migration and movement corridors. Landscape Ecol. 30, 15271540 .

Stammler, F.M., 2014. Cumulative impacts of socio-cultural and environmental changes among Siberian reindeer pastoralists, in: Association for the Promotion of Northern Cultures, The Proceedings of the $28^{\text {th }}$ International Abashiri Symposium, pp. 29-35.

Stammler, F.M., Ivanova, A., 2016. Resources, rights and communities: extractive megaprojects and local people in the Russian Arctic. Europe-Asia Stud. 68, 1220-1244.

Turunen, M. T., Rasmus, S., Bavay, M., Ruosteenoja, K., Heiskanen, J., 2016. Coping with difficult weather and snow conditions: Reindeer herders' views on climate change impacts and coping strategies. Clim. Risk Manag. 11, 15-36.

van Schie, R., Haider, W., 2015. Indigenous-based approaches to territorial conservation: A case study of the Algonquin Nation of Wolf Lake. Conserv. Soc. 13, 72.

Vistnes, I., Burgess, P., Mathiesen, S. D., Nellemann, C., Oskal, A., Turi, J. M., 2009. Reindeer Husbandry and Barents 2030: Impacts of Future Petroleum Development on Reindeer Husbandry in the Barents Region. https://gridarendal-website-

live.s3.amazonaws.com/production/documents/:s document/220/original/reindeer-husbandrybarents lores.pdf?1486728194 Last access 30 May, 2018.

Whyte, K., 2016. Indigenous peoples, climate change loss and damage, and the responsibility of settler states. http://dx.doi.org/10.2139/ssrn.2770085

Wilson, E., 2017. What is Social Impact Assessment? Indigenous peoples and resource extraction in the Arctic: evaluating ethical guidelines. Árran Lule Sami Centre project report, January 2017. http://www.academia.edu/32010168/What_is social impact assessment Last access 30 May, 2018. 


\section{Online supplemental material}

Supplementary table S1. Interviewees: list of organizations

\begin{tabular}{|c|c|c|}
\hline Stakeholder types & Name of organisation & $\mathbf{N}$ \\
\hline \multicolumn{3}{|l|}{ HERDERS } \\
\hline $\begin{array}{l}\text { Governmental organization } \\
\text { (other) }\end{array}$ & Reindeer Herders' Association & 2 \\
\hline $\begin{array}{l}\text { Herding cooperative (local } \\
\text { community) }\end{array}$ & Sattasniemen paliskunta & 1 \\
\hline $\begin{array}{l}\text { Herding cooperative (local } \\
\text { community) }\end{array}$ & Syväjärven paliskunta & 1 \\
\hline $\begin{array}{l}\text { Herding cooperative (local } \\
\text { community) }\end{array}$ & Tolvan paliskunta & 1 \\
\hline $\begin{array}{l}\text { Herding cooperative (local } \\
\text { community) }\end{array}$ & Kuivasalmen paliskunta & 1 \\
\hline $\begin{array}{l}\text { Herding cooperative (local } \\
\text { community) }\end{array}$ & Oraniemen paliskunta & 1 \\
\hline $\begin{array}{l}\text { Herding cooperative (local } \\
\text { community) } \\
\text { NGO }\end{array}$ & Kemin-Sompion paliskunta & 2 \\
\hline Environmental NGO & The Finnish Association for Nature Conservation & 1 \\
\hline \multicolumn{3}{|l|}{ DEVELOPERS } \\
\hline $\begin{array}{l}\text { Private company (developer; wind } \\
\text { mills) }\end{array}$ & EPV Tuulivoima Oy & 1 \\
\hline $\begin{array}{l}\text { Private company (developer; } \\
\text { mining) }\end{array}$ & Agnico Eagle Finland Oy & 1 \\
\hline $\begin{array}{l}\text { Private company (developer; } \\
\text { mining) }\end{array}$ & Boliden Finland Oy & 1 \\
\hline $\begin{array}{l}\text { Private company (developer; } \\
\text { mining) }\end{array}$ & Yara Finland Oy & 2 \\
\hline $\begin{array}{l}\text { State-owned enterprise } \\
\text { (developer; wind mills) } \\
\text { PUBLIC AUTHORITIES }\end{array}$ & Metsähallitus Laatumaa & 1 \\
\hline $\begin{array}{l}\text { Governmental agency (EIA } \\
\text { coordinating body) }\end{array}$ & $\begin{array}{l}\text { ELY, Centre for Economic Development, Transport and the } \\
\text { Environment (Lapland) }\end{array}$ & 4 \\
\hline $\begin{array}{l}\text { Governmental agency (EIA } \\
\text { coordinating body) }\end{array}$ & $\begin{array}{l}\text { ELY, Centre for Economic Development, Transport and the } \\
\text { Environment (Northern Ostrobothnia) }\end{array}$ & 1 \\
\hline Governmental agency (other) & AVI, Regional State Administrative Agency & 1 \\
\hline Governmental agency (other) & TUKES, the Finnish Safety and Chemicals Agency & 1 \\
\hline Governmental agency (other) & Lapin liitto, Regional Council of Lapland & 1 \\
\hline Governmental agency (other) & Ministry of the Environment & 1 \\
\hline \multicolumn{3}{|l|}{ CONSULTANTS } \\
\hline Private company (consulting) & Pöyry Finland Oy & 3 \\
\hline Private company (consulting) & Sito Oy & 2 \\
\hline Private company (consulting) & Lapin vesitutkimus Oy & 1 \\
\hline $\begin{array}{l}\text { Total number of interviewees } \\
\text { (persons) }\end{array}$ & & 31 \\
\hline
\end{tabular}


Supplementary table S2. Semi-structured interview questions.

\section{Main questions}

Engagement What was your role in the EIA process of the current infrastructure type development project?

Have you participated in (other) planning processes on infrastructure development in your community? (question mainly for herders)

Do you wish to be more actively engaged into the planning processes on infrastructure development in the future, and if so, how? (question mainly for herders)

Benefits of What do you see as benefits of participatory processes?

participation

Efficiency of participation

Timing of participation

Need of project Legitimacy of the project
Do you feel that herders' voice has been heard in the EIA process, and did herders have any effect on the project outcome?

In which phases of planning should participatory processes take place? Why?

Do you think that this type of infrastructure development is needed in Finland in general? What are the national benefits of this project, if any?

Do you think this project is needed in the community?

What are the local benefits, if any?

To your knowledge, how are the needs of public reflected in the EIA process of the current infrastructure project?

Location of the project

Transparency of information

Type of information and understandabilit $\mathrm{y}$ Information sources

Trust to information sources
What do you think about the location of the project?

Do you think that you have clear and sufficient amount of information for the infrastructure project you are planning (developers/consultants/government agencies) / of the infrastructure project by which you are affected (herders)? Was information, which you have received or asked for, understandable? If not, please explain why.

Considering the current infrastructure development project, from which sources do you gain information for it (developers/consultants/government agencies) / on it (herders)? Do you consider these sources of information trustworthy for your purposes?

Which sources of information would you not feel are trustworthy? Why? 
Do you think anyone is withholding information? If yes, why?

\begin{tabular}{ll}
\hline $\begin{array}{l}\text { Risks and } \\
\text { impacts }\end{array}$ & $\begin{array}{l}\text { What are the major risks and impacts of this project for your } \\
\text { community? For Finland in general? }\end{array}$ \\
& $\begin{array}{l}\text { From your perspective, how can reindeer husbandry be prepared for } \\
\text { risks and impacts from industrial development? }\end{array}$ \\
Responsibility & $\begin{array}{l}\text { Who do you think will bear the risks and costs, and who will bear the } \\
\text { benefits? Do you think this is fair? }\end{array}$ \\
Compensation & $\begin{array}{l}\text { To your knowledge, what kind of compensation is (will be) provided to } \\
\text { herders and who provides it? }\end{array}$ \\
& $\begin{array}{l}\text { Is it necessary or sufficient in your opinion? Should there be any other } \\
\text { type of compensation? }\end{array}$ \\
& $\begin{array}{l}\text { Do you think compensation is a workable and fair option, that is, are } \\
\text { there impacts for which compensation is inappropriate? }\end{array}$ \\
Climate change & $\begin{array}{l}\text { Do you believe climate change is happening, and, if so, how is it } \\
\text { affecting this region? (question mainly for herders) }\end{array}$ \\
Adaptation & $\begin{array}{l}\text { What do you see as limitations for reindeer herders to adapt to climate } \\
\text { change and land use change? }\end{array}$ \\
\hline
\end{tabular}

